\title{
Jurnal Ilmiah Iqra'
}

2541-2108 [Online] 1693-5705 [Print]

Tersedia online di: http://journal.iain-manado.ac.id/index.php/JII

\section{Pembelajaran Bahasa Arab Sebagai Upaya Pembentukan Karakter Santri di Pondok Pesantren}

\author{
Hasnil Oktavera \\ Fakultas Tarbiyah dan IImu Keguruan IAIN Manado \\ hasniloktavera@iain-manado.ac.id
}

\begin{abstract}
Abstrak
Penelitian ini berawal dengan adanya kecurigaan peneliti terhadap peran kajian bahasa Arab dalam pembentukan karakter santri di Pondok Pesantren dengan memotret kegiatan berbahasa Arab di Pondok Pesantren terutama pada Pondok Pesantren modern dan Pondok Pesantren konvensional (salafi). Fokus utama analisis adalah penggunaan bahasa Arab serta aktifitas berbahasa Arab baik di dalam maupun diluar kelas.

Hasil penelitian menunjukkan bahwa, pembelajaran bahasa Arab dapat membantu pembentukan karakter santri secara berkesinambungan dengan ditopang oleh kehadiran sistem dan corak pembelajaran bahasa Arab di Pondok Pesantren. Corak dan sistem tersebut membentuk karakter santri, diantaranya karakter komunikatif, disiplin, relegius dan beretika, toleran dan bertanggungjawab, kemandirian dan percaya diri, serta penghargaan.
\end{abstract}

Kata kunci: Pembelajaran Bahasa Arab, Pembentukan Karakter, Pondok Pesantren

\begin{abstract}
This study began with the researchers' suspicion of the role of Arabic studies in shaping the character of students in the Islamic Boarding School by photographing Arabic activities in the Boarding School especially in modern Boarding School and conventional Boarding School (Salafi). The main focus of the analysis is the use of Arabic and Arabic language activities both inside and outside the classroom.

The results showed that, learning Arabic could help the formation of the character of students in a sustainable manner supported by the presence of Arabic learning systems and patterns in Pondok Penatren. The patterns and systems form the character of the santri, including communicative, disciplined, religious and ethical character, tolerant and responsible, independence and confidence, and appreciation.

Keywords: Learning Arabic, Forming Characters, Islamic Boarding Schools.s
\end{abstract}




\section{Pendahuluan}

Masyarakat Indonesia yang berkarakter pada era disrupsi adalah sebuah tuntutan sebagai upaya menyelamatkan generasi bangsa agar terlepas dari belenggu penjajahan moral dari berbagai aspek, baik itu pada aspek akademik, politik, agama dan sosial kemasyarakatan sehingga mereka unggul dalam mengahadapi tantangan global yang bersifat terstruktur, terencana, tersistematis dan massif. Penyelamatan awal yang ditawarkan kepada pemerintah adalah pendidikan moral disetiap jenjang pendidikan.

Tuntutan tersebut tidak serta merta terejawantahkan pada kurikulum yang di rancang oleh pemerintah yang selanjutnya di implementasikan pada lembaga pendidikan formal seperti di sekolah-sekolah, madrasah-madrasah dan Pondok Pesantren. Lembaga pendidikan tersebut mempunyai cara sendiri dalam membentuk karakter peserta didiknya, baik yang tersajikan dalam bentuk kegiatan ekstra-kurikuler maupun terimplementasikan pada pembiasaan yang bersifat hidden curriculum. Pembentukan karakter melalui kegiatan ekstra-kurikuler tercermin pada penyaluran bakat dan minat siswa serta adanya bimbingan dan konseling yang terstruktur, sedangkan pembentukan karakter melalui pembiasaan yang bersifat hidden curriculum adalah melalui kantin kejujuran, pembinaan akidah akhlak, pembiasaan berlaku sopan dan hormat kepada guru dan lain sebagainya.

Pembentukan karakter sebenarnya juga berlangsung pada pembelajaran bahasa Arab di berbagai Pondok Pesantren (Izfanna \& Hisyam, 2012). Tradisi Pondok Pesantren yang meniscayakan bahasa Arab sebagai suatu keharusan yang mesti dipelajari, ternyata menyimpan berbagai kesan yang mendalam, sehingga pembelajaran bahasa Arab diberbagai Pondok Pesantren menjadi pembelajaran yang tidak boleh dilenyapkan meskipun tergolong pada pembelajaran konvensional dalam penerapannya. Karakteristik pembelajaran bahasa Arab di Pondok Pesantren yang tergolong heterogen merupakan ciri khas dalam membentuk jiwa santri menjadi lebih berkarakter.

Penelitian ini bertujuan mengungkapkan sisi-sisi karakter para santri yang terbangun melalui pembelajaran bahasa Arab, sehingga diperoleh informasi karakter-karakter yang muncul ketika mempelajari bahasa Arab di Pondok Pesantren. Fokus utama pada penelitian ini adalah aktifitas-aktifitas bahasa Arab di pondok pesantren dan peranannya dalam membentuk karakter santri. 


\section{Kajian Teori}

\section{Pembelajaran Bahasa Arab}

Bahasa Arab merupakan salah satu bahasa yang memiliki keunikan dengan sifat fonetik, sintaksis dan morfologinya yang kompleks sehingga menjadikannya istimewa dibandingkan dengan bahasa dunia lainnya. Diantara keistimewaan bahasa Arab adalah: 1) bahasa yang kaya dengan koskata, 2) bahasa yang memiliki analisa struktur (i'rab) yang lengkap, 3) bahasa yang mempunyai sistem pembentukan kata (morfologi) yang unik, 4) bahasa yang fleksibel dan dinamis, 4) bahasa yang memiliki gaya bahasa yang halus (balaghah)(Garancang, 2010). Keistimewaan ini lah merupakan salah satu alasan bahasa Arab menjadi suatu keharusan untuk dipelajari, baik untuk tujuan identitas (Wahyuni, 2017) maupun untuk tujuan komunikasi. Perkembangan kajian bahasa Arab dalam menghadapi tujuan tersebut mengandung kompetensi bahasa yang menjadi prasyarat utama dalam menguasai suatu bahasa baik pada pemerolehan bahasa maupun pada pembelajaran bahasa.

\section{Pendidikan Karakter}

Pendidikan pada hakikatnya adalah suatu kesadaran yang utuh dalam menciptakan suasana pembelajaran yang mampu mengolah dan mengembangkan potensi positif peserta didik sehingga mereka memiliki jiwa relegius, control diri, kepribadian, kecerdasan, akhlak dan terampil. Dalam rangka memperkuat potensi positif tersebut maka di dukung dengan karakter. Setiap individu memiliki karakternya masing-masing sehingga untuk menumbuhkan itu maka muncullah pendidikan karakter.

Kamus Besar Bahasa Indonesia mendefinisikan karakter dengan sifat-sifat kejiwaan, tabiat, akhlak, kepribadian (Majid \& Andayani, 2011), dan secara subtantif, karakter pada intinya adalah kekuatan dan orisinalitas dalam diri seseorang yang memiliki reputasi yang baik, karena karakter adalah penjelmaan sifat dari kejiwaan yang muncul dalam diri seseorang baik hubungannya dengan Tuhan Yang Maha Esa, sesama manusia maupun pada diri sendiri (Fitri, 20112).

Karakter terwujud dalam kehidupan keseharian yang dinamai dengan pilarpilar karakter, diantaranya: 1) Karakter Cinta Tuhan dan segenap ciptaan-Nya, 2) Kemandirian dan tanggungjawab, 3) Kejujuran, amanah, dan diplomatis, 4) hormat dan santun, 5) Dermawan, suka menolong dan gotong-royong, 6) Percaya diri dan 
pekerja keras, 7) kepemimpinan dan keadilan, 8) baik dan rendah hati, dan 9) Toleransi, kedamaian dan kesatuan (Megawati, 2007)

\section{Metode Penelitian}

Penelitian ini memotret berbagai kegiatan berbahasa Arab di Pondok Pesantren terutama pada Pondok Pesantren modern dan Pondok Pesantren konvensional (salafi). Fokus utama analisis adalah penggunaan bahasa Arab serta aktifitas berbahasa Arab baik di dalam maupun diluar kelas. Variabel pembentukan karakter santri dijadikan sebagai pendukung penelitian merupakan kriteria utama dengan mempertimbangkan adanya pembentukan karakter di Pondok Pesantren dan bahasa Arab dijadikan sebagai kajian wajib di Pondok Pesantren. Hal ini mengindikasikan adanya kecurigaan peneliti bahwa adanya peran kajian bahasa Arab dalam pembentukan karakter pada santri di Pondok Pesantren.

Sejumlah data yang tidak sesuai dengan masalah penelitian diabaikan walaupun hal tersebut merupakan aktifitas yang lazim di Pondok Pesantren. Kemudian data yang didapatkan dianalisis dan diuji untuk mendeskripsikan adanya pelaksanaan aktifitas yang dimaksud dan berlangsung secara sistematis. Dengan demikian, jenis penelitian ini adalah lapangan dengan menggunakan pendekatan kualitatif dalam bentuk penelitian studi kasus di Pondok Pesantren.

\section{Hasil dan Pembahasan}

\section{Budaya Belajar Bahasa Arab di Pondok Pesantren}

Bahasa Arab di berbagai Pondok Pesantren merupakan kajian wajib dipelajari oleh santri dengan menyeimbangkan aspek kemahiran berbahasa dan aspek unsurunsur berbahasa. Meskipun telah berusaha menyeimbangkan kompetensi berbahasa tersebut, namun di berbagai Pondok Pesantren memiliki corak yang khas dalam pembelajaran bahasa Arab. Seperti Pondok Pesantren Gontor yang lebih menekankan aspek kemahiran berbicara dibanding aspek qawa'id. Berbeda di Pondok Pesantren Lirboyo yang lebih menekankan pada aspek qira'ah dan qawa'id yang teraplikasikan pada kemahiran dalam membaca kitab standar.

Penekanan pada aspek kemahiran berbicara lebih banyak dijumpai pada Pondok Pesantren modern, sedangkan penekanan pada aspek kemahiran membaca dan kaidah-kaidah berbahasa lebih banyak ditemukan pada Pondok Pesantren konvensional (salafi). Variasi yang berbeda pada pembelajaran bahasa Arab di 
Pondok Pesantren pada dasarnya tidak menghilangkan substansi kajian bahasa Arab itu sendiri, hanya saja lebih pada menyesuaikan dengan situasi, visi dan misi dari program tersebut.

Situasi, visi dan misi pada Pondok Pesantren diselaraskan dengan misi agama dengan memusatkan kajian bahasa Arab sebagai media dalam memahami al-Qur'an, Hadits dan kitab-kitab turats. Sehingga alokasi waktu pembelajaran bahasa Arab di Pondok Pesantren menjadi lebih dominan dibandingkan dengan kajian keilmuan lainnya.

Kedominanan kajian bahasa Arab di Pondok Pesantren ini menyebabkan adanya kesakralan para santri terhadap kajian bahasa Arab, sehingga muncul paradigma berfikir para santri yang menyatakan bahwa Pondok Pesantren itu tidak bisa berjalan sesuai dengan fungsinya jika tidak ada kajian bahasa Arab didalamnya. Hal ini sejalan dengan pendapatnya Ramadhan Abdu Al-Tawwab yang menyatakan bahwa jikalau tidak ada al-Qur'an, maka tidak ada bahasa Arab, dan jikalau tidak ada bahasa Arab sulit untuk memahami al-Qur'an dan agama Islam (Al-Tawwab, 1994). Dengan alasan tersebut maka muncul berbagai pola dan metode pengajaran bahasa Arab di Pondok Pesantren mulai dari metode dan pola pengajaran klasik hingga ke modern.

Kemunculan berbagai pola dan metode pembelajaran bahasa Arab di Pondok Pesantren mencerminkan pola pembentukan karakter santri. Sehingga corak Pondok Pesantren yang ada di Indonesia memiliki dua tipikal pembelajaran bahasa Arab, yaitu corak pembelajaran bahasa Arab di Pondok Pesantren modern dan corak pada Pondok Pesantren konvensional atau salafi. Meskipun dua tipikal Pondok Pesantren ini masih menjadi perdebatan yang panjang dalam hal penamaannya (Rozak, 2018).

Pembelajaran bahasa Arab yang bercorak modern sangat bercorak integratif dengan menghubungkan aspek pembelajaran bahasa Arab dengan kehidupan keseharian para santri untuk memperoleh pengalaman-pengalaman belajar yang tidak hanya di ajarkan didalam kelas tapi juga pada lingkungan sekitar Pondok Pesantren (Syamsu, 2018). Model pembelajaran bahasa Arab seperti ini lebih menekankan pada aspek berbicara (maharat Al-Takallum) dibandingkan dengan struktur berbahasa (Qawaid Al-Lughawiyah).

Sedangkan Pondok Pesantren yang bercorak salafi terus membudayakan kajian kitab-kitab turats yang berasal dari timur tengah sebagai rujukan utama 
dalam mengkaji dan mendalami Islam. Hanya saja terdapat berbagai kesulitan para santri yang disebabkan kandungan dan struktur kalimat bahasa Arab yang tinggi dan para santri hanya diarahkan pada kemampuan memahami kaidah bahasa dan menerjemahkan saja, sedangkan pada aspek bahasa sebagai alat komunikasi lisan tidak terlakasana. Corak yang seperti ini lebih menekankan pada kajian studi Islam dari literatur-literatur klasik.

\section{Pembelajaran Bahasa Arab dan Pembentukan Karakter}

Pembentukan karakter para santri di yang tercermin pada pembelajaran bahasa Arab terbagi dalam berbagai bentuk karakter, diantaranya komunikatif, kedisiplinan, relegius dan beretika, toleran dan bertanggungjawab, kemandirian dan percaya diri, serta penghargaan.

1. Komunikatif dan Ramah Berbahasa

Pondok Pesantren yang menekankan pada keterampilan berbahasa pada aspek berbicara (kalam) lebih menonjolkan komunikasi yang baik dengan sesama santri. Para santri dibekali dengan ungkapan-ungkapan dan gaya bahasa (ta'bir wa uslub) yang ada dalam bahasa Arab dan kemudian mempraktekkannya dalam percakapan keseharian para santri. Seperti ungkapan "man sabara zafira" yang tercermin dalam percakapan "I'lam ya shadiqy ala anna man sabara zafira".

Aspek komunikatif tersebut menunjukkan adanya karakter yang kuat yang ditanamkan pada santri tanpa harus menuntut adanya kebenaran kaidah dan struktur bahasa sehingga para santri mampu mengungkapkan ide, pikiran dan perasaannya kepada sesama santri.

Pola komunikasi seperti ini memperkuat kepribadian santri untuk selalu berinteraksi dengan baik dan sopan. Indikator kesopanan komunikasi para santri tergambar dengan gaya bahasa yang baik sehingga pendengar dapat memahami dan mengkomunikasikan bahasa tersebut, sehingga tercipta lingkungan berbahasa yang ramah dilingkungan santri.

Lingkungan yang ramah berbahasa dilingkungan santri diperkuat dengan adanya hafalan dan pemahaman kitab matan alfiah ibnu malik. Kitab ini banyak mengandung kaidah-kaidah bahasa Arab yang mudah difahami melalui syair, dan syair tersebut mengandung ungkapan-ungkapan yang berbentuk nasehat-nasehat, sehingga membantu para santri mengungkapkan ide dan perasaannya dalam berkomunikasi dalam berbahasa Arab. 
2. Disiplin

Aktifitas berbahasa Arab di Pondok Pesantren merupakan kewajiban bagi santri. Aktivitas tersebut berlangsung di masjid, pendopo, dapur, lapangan yang telah tersedia papan tulis sebagai media untuk menuliskan koskata (Wekke, 2014). Aktivitas tersebut dimulai dari bangun tidur hingga kembali tidur dengan mewajibkan para santri menggunakan bahasa Arab saat berkomunikasi, seperti pengumuman secara lisan dan tulisan, slogan-slogan motivasi, perlombaan syi'ir dan drama serta membaca berita. Semua aktivitas tersebut dilakukan dengan menggunakan bahasa Arab. Kedisiplinan penggunaan bahasa Arab ini bertujuan untuk menunjang disiplin ilmu yang lainnya. Sehingga jika disiplin bahasa ini tidak berjalan dikalangan santri, maka mahkamah bahasa memberikan teguran dan hukuman.

Teguran dan hukuman yang diterapkan oleh mahkamah bahasa di Pondok Pesantren bertujuan untuk meningkatkan kedisiplinan santri dalam berbahasa dengan tujuan untuk meningkatkan kompetensi berbahasa dikalangan santri.

\section{Relegius dan beretika}

Aspek karakter relegius dan beretika hamper tidak bisa dibedakan pada santri. Karena aspek kehidupan beretika dan relegius santri berjalan beriringan. Aspek bahasa Arab yang sering muncul dalam kehidupan santri terutama dalam memunculkan karakter relegius dan etika adalah pada kalimat sapaan, ungkapanungkapan senang, sedih, syukur, kaget, takjub dan lain sebagainya dengan menggunakan uslub-uslub yang mengandung unsur relegius. Seperti masya Allah, subhanallah untuk ungkapan rasa kagum, ungkapan al-hamdulillah, syukran lillah 'ala ni'amihi untuk mengungpkan rasa senang dan syukur, ungkapan astagfirullaha alazhim untuk ungkapan kaget dan sedih.

Ungkapan tersebut muncul dalam percakapan bahasa Arab sehari-hari secara spontan. Kemampuan seperti ini menjadi dukungan nyata para santri dalam berinteraksi didalam kehidupan sosial yang lebih luas. Menggunakan kata-kata yang memiliki unsur bahasa Arab dalam konteks tertentu merupakan karakter para santri dalam memposisikan diri ditengah masyarakat.

Kegemaran dalam berbahasa dan menggunakan bahasa Arab merupakan jalan mudah untuk menjadi seorang muslim dan mengajak orang lain mengenal Islam lebih dekat dan lebih mudah dengan mengungkapkan ujaran yang Islami dan bernuansa transendental. Selain tercermin dalam percakapan keseharian para 
santri, juga terpapar dalam materi-materi ajar yang disuguhkan oleh para kiyai dengan bahasa Arab sebagai bahasa pengantarnya baik yang menggunakan materi dalam kitab-kitab klasik (turats) maupun materi yang diambil dalam buku-buku yang ditulis oleh kiyai sendiri.

4. Toleran dan bertanggungjawab

Materi bahasa Arab yang diajarkan di Pondok Pesantren baik yang modern maupun yang konvensional adalah berjenjang sesuai dengan tingkat pemahaman kebahasaan mereka. Ada yang berada pada tingkat pemula (mubtadi'), menengah (mutawassith) dan lanjut (aliy). Ketika terdapat santri yang memiliki kemampuan bahasanya rendah, maka menjadi suatu kewajiban bagi santri yang memiliki kemampuan bahasanya cukup memadai untuk mengajarkannya selain dia juga mendapatkan tambahan materi dikelas tanpa memandang tingkat sosial, suku dan daerah asalnya.

Toleransi yang terpapar tersebut mendapatkan andil dalam pelayanan kebahasaan para santri. Para santri tidak merasa canggung dalam menyampaikan maksud dan tujuannya dalam berbahasa Arab.

5. Kemandirian dan Kepercayaan diri

Salah satu tradisi Pondok Pesantren yang tidak pernah lenyap adalah kemandirian para santri, sehingga landasan utama pengembangan kurikulum Pondok Pesantren adalah kemandirian santrinya (Wekke, 2014). Sebagai wujud nyata, maka santri di dorong untuk memaksimalkan diri untuk berkalaborasi dengan buku-buku yang berbahasa Arab, baik buku yang berkenaan dengan al-Qur'an, Hadits, fikih, tasawuf dan lain sebagainya. Dengan demikian peluang santri untuk memperoleh pengalaman belajar cukup tinggi, sementara tenaga pengajar hanyalah membantu santri dalam mencapai efektifitas belajar.

Pengalaman belajar yang diperoleh santri berupa aktifitas berbagai perlombaan seperti pidato bahasa Arab (muhadarah), setoran hafalan kosakata (Taqdim Al-Mufradat), percakapan (Muhadatsah), Upacara dengan menggunakan bahasa Arab (Siddiq, 2017), pemahaman keagamaan melalui media bahasa Arab dan dukungan lingkungan berbahasa (bi'ah lughawiyah).

Selain itu, para santri juga melakukan dialog dengan teman sebaya mengenai konten-konten keilmuan yang dikaji. Sehingga kesadaran untuk berkalaborasi dan berinteraksi dengan teman sebaya melatih kemandirian para santri untuk menerima 
setiap perbedaan, karena interaksi yang intensif di lingkungan sangat membantu proses pendidikan dan pembelajaran (Raihani, 2012). Budaya kemandirian ini terus berlanjut ketika para santri telah menjadi alumni dengan membentuk berbagai komunitas kajian Islam yang lebih luas.

6. Memberi penghargaan

Kualitas pemberian penghargaan kepada seseorang bisa diukur pada tingkat bahasa yang dipakai. Pada pembelajaran bahasa Arab, pembahasaan untuk santri yang berprestasi di tunjukkan dengan ungkapan pujian "Ahsanta/ahsanti, Mumtaz" dan tidak menggukan kata-kata "jamil, thayyib". Karena kata "ahsanta/ ahsanti, mumtaz" adalah kata-kata yang digunakan untuk memuji sesuatu yang luar biasa. Penghargaan yang tinggi diberikan kepada santri seolah-olah apa yang dilakukan oleh santri itu adalah luar biasa sehingga mereka memiliki motivasi dan semangat untuk terus belajar.

\section{Kesimpulan}

Berdasarkan pembahasan tersebut di atas, dapat disimpulkan bahwa pembelajaran bahasa Arab dapat membantu pembentukan karakter santri secara berkesinambungan dengan ditopang oleh kehadiran sistem dan pola pembelajaran di Pondok Pesantren. Kehadiran pola dan sistem pembelajaran bahasa Arab memunculkan karakter yang identik pada santri yaitu karakter komunikatif, disiplin, relegius dan beretika, toleran dan bertanggungjawab, kemandirian dan percaya diri, serta penghargaan.

\section{Referensi}

Al-Tawwab, R. A. (1994). Fiqh Al-Arabiyah. Al-Qahirah: Maktabah Al-Khanja.

Fitri, A. Z. (20112). Pendidikan Karakter Berbasis Nilai dan Etika di Sekolah. Yokyakarta: Ar-Ruzz Media.

Garancang, S. (2010). Problematika Pengajaran Bahasa Arab pada Perguruan Tinggi Islam. Jurnal Sosio-Religia, 2(2).

Izfanna, D., \& Hisyam, N. M. (2012). A Comprehensive Approach in Developing Akhlaq. Multicultural Education and Technologhy Journal, 6(6), 77.

Majid, A., \& Andayani, D. (2011). Pendidikan Karakter dalam Prespektif Islam. Bandung: Remaja Rosdakarya. 
Megawati, R. (2007). No Title. Bogor: : Indonesia Haritage Foundation.

Raihani. (2012). Report on Multicultural Education in Pesantren. Journal of Comparative and International Education Compare, 42(4), 585-605.

Rozak, A. (2018). Modernisme Pembelajaran Bahasa Arab Berbasis Pesantren di Rangkasbitung Banten. Journal of Arabic Studies, 3(2), 167-180.

Siddiq, M. (2017). Pembelajaran Bahasa Arab di Pondok Pesantren Darunnajah Jakarta (Studi Etnografi),. Al-Ma'rifah, 14(2), 24-36.

Syamsu, P. K. (2018). Bahasa Arab di Pondok Modern Darussalam Gontor. El-lbtikar, $7(2), 18-40$.

Wahyuni, I. (2017). Bahasa Arab dalam Konteks Simbol Agama; Analisis Terhadap Tujuan Pembelajaran pada Perguruan Tinggi Islam. Zawiyah Jurnal Pemikiran Islam, 3(2), 78-92.

Wekke, I. S. (2014). Tradisi Pesantren dalam Konstruksi Kurikulum Bahasa Arab di Lembaga Pendidikan Minoritas Muslim Papua Barat. Karsa, 22(1), 21-39. 